\title{
Moellerella wisconsensis
}

National Cancer Institute

\section{Source}

National Cancer Institute. Moellerella wisconsensis. NCI Thesaurus. Code C86521.

A species of facultatively anaerobic, Gram negative, rod shaped bacterium in the phylum Proteobacteria. This species is nonmotile, indole negative, resistant to colistin, lactose positive and produces acid from D-glucose, lactose and raffinose. M. wisconsensis is found in water and may be associated with diarrheal symptoms in humans. 